\title{
Physicochemical characteristics of meat from pantaneiro lambs slaughtered with different of subcutaneous fat thicknesses
}

\section{Características físico-químicas da carne de cordeiras pantaneiras abatidas com diferentes espessuras de gordura subcutânea}

\author{
Natália Holtz Alves Pedroso Mora ${ }^{1 *}$; Francisco de Assis Fonseca de Macedo ${ }^{2}$; \\ Alexandre Agostinho Mexia ${ }^{3}$; Fernanda Losi Alves de Almeida ${ }^{2}$; \\ Franciane Barbiéri Dias Senegalhe ${ }^{4}$; Ana Paula Silva Possamai ${ }^{1}$; \\ Rosa Maria Gomes de Macedo ${ }^{2}$; Gherman Garcia Leal Araújo ${ }^{5}$
}

\begin{abstract}
Twenty-four lambs of the pantaneiro genetic group were used in a completely randomized design with eight replicates, slaughtered with subcutaneous fat thicknesses (SFT) of 2.0, 3.0 and $4.0 \mathrm{~mm}$, which was evaluated by ultrasound in the longissimus dorsi muscle to measure the effect of the SFT on the physicochemical properties of the meat. The animals received water ad libitum throughout the experimental period and were fed a complete, pelleted ration formulated to provide an average daily gain of $0.300 \mathrm{~kg}^{-1}$. As the lambs reached the predetermined SFT in the fortnightly evaluation by ultrasound, they were slaughtered the day after the measurements, regardless of weight. The $\mathrm{pH}$ values for $0 \mathrm{~h} 00$ (6.58) and 24h00 (5.50) and cooking loss (23.99\%) did not differ between treatments. Regarding the meat color, lambs slaughtered with $2.0 \mathrm{~mm}$ and $3.0 \mathrm{~mm}$ SFT had meat with greater lightness and the meat from those with 3.0 and $4.0 \mathrm{~mm}$ SFT showed higher values for the intensity of red and yellow. Lambs slaughtered with $4.0 \mathrm{~mm}$ SFT (1.43 kgf) had more tender meat than those slaughtered with a SFT of $2.0 \mathrm{~mm}$. Lambs slaughtered with $4.0 \mathrm{~mm}$ SFT had the greatest sarcomere length $(1.47 \mu \mathrm{m})$. The crude protein $(21.15 \%)$ and moisture $(72.38 \%)$ contents in the $2.0 \mathrm{~mm}$ treatment were higher than those in the $4.0 \mathrm{~mm}$ treatment. The total lipids $(4.84 \%)$ in the meat from $4.0 \mathrm{~mm}$ SFT animals were higher than those in the meat from $2.0 \mathrm{~mm}$ SFT lambs. Slaughtering lambs with $3.0 \mathrm{~mm}$ of fat thickness in the loin is recommended, as these animals comprise a larger number of favorable characteristics with regard to the meat chemical composition, softness, and color.
\end{abstract}

Key words: Color, cooking, feedlot, sarcomere, tenderness

\section{Resumo}

Foram utilizadas 24 cordeiras do grupo genético pantaneiro em delineamento inteiramente casualizado com oito repetições, abatidas com 2,0;3,0 e 4,0 mm de espessura de gordura, avaliadas por ultrassonografia no Longissimus dorsi para aferir o efeito da espessura de gordura subcutânea sobre as características

\footnotetext{
${ }^{1}$ Discentes, Universidade Estadual de Maringá, UEM, Maringá, PR, Brasil. E-mail: natalia-mora@hotmail.com; anapaula_ possamai@hotmail.com

2 Profs., UEM, Maringá, PR, Brasil. E-mail: fafmacedo@uem.br, flaalmeida@uem.br; rmgmacedo@uem.br

3 Prof., Universidade do Estado do Mato Grosso, UNEMAT, Tangará da Serra, MT, Brasil. E-mail: alexandre@unemat.com

${ }^{4}$ Discente, Universidade Federal da Grande Dourados, UFGD, Dourados, MS, Brasil. E-mail: francibardi_08@hotmail.com

${ }_{5}$ Pesquisador, Empresa Brasileira de Pesquisa Agropecuária, EMBRAPA, Centro de Pesquisa Agropecuária do Trópico SemiÁrido, Petrolina, PE, Brasil. E-mail: gherman.araujo@embrapa.br

* Author for correspondence
} 
físico-químicas da carne. Os animais receberam água à vontade durante todo o período experimental e foram alimentados com ração total peletizada, formulada para um ganho de peso diário de $0,300 \mathrm{~kg}$ animal $^{-1}$. Conforme as cordeiras atingiam a espessura de gordura pré-determinada na avaliação semanal por ultrassonografia, as mesmas eram abatidas no dia seguinte às aferições, independentemente do peso. $\mathrm{O}$ pH 0 hora $(6,58) ; 24$ horas $(5,50)$ e perdas por cocção $(23,99 \%)$ não diferiram entre os tratamentos. Os ovinos abatidos com 2,00 mm e 3,00 mm apresentaram carne com maior luminosidade e as com 3,00 e 4,00 $\mathrm{mm}$ foram superiores para intensidade de vermelho $\mathrm{a}^{*} \mathrm{e}$ intensidade de amarelo $\mathrm{b}^{*}$. Fêmeas abatidas com 4,00 $\mathrm{mm}$ de espessura de gordura (1,43 kgf) apresentaram carne mais macia que as de 2,00 mm. Cordeiras abatidas com 4,00 $\mathrm{mm}$ de espessura de gordura apresentaram maiores valores $(1,47 \mu \mathrm{m})$ para comprimento de sarcômero. A proteína bruta $(21,15 \%)$ e umidade $(72,38 \%)$ das amostras do tratamento $2,00 \mathrm{~mm}$ foram superiores aos de 4,00 $\mathrm{mm}$. Os lipídeos totais $(4,84 \%)$ na carne dos animais abatidos com 4,00 $\mathrm{mm}$ foram superiores aos de 2,00 mm. Recomenda-se o abate de cordeiras com 3,00 $\mathrm{mm}$ de espessura de gordura no lombo, pois englobaram maior número de características favoráveis em relação à composição química da carne, maciez e coloração.

Palavras-chave: Cor, cocção, confinamento, maciez, sarcômero

\section{Introduction}

Meat is important in human feeding worldwide because of its high-quality protein and presence of essential amino acids, as well as its vitamin and mineral salt content. According to Missio et al. (2010), the consumer demands for meat color, tenderness, palatability, and juiciness are growing constantly, and these are the main factors to retain consumers and gain market ground.

In this scenario, enhancing and maximizing the productive potential of the different species accross the varied demographic regions has become paramount to economic development. For instance, according to Vargas Junior et al. (2011), the Brazilian states of Mato Grosso and Mato Grosso do Sul have a sheep genetic group named pantaneiro, originating from several crossings throughout years that underwent natural selection to the climatic conditions of that region, and whose main ancestors are animals from the South and Northeast of Brazil. However, there are few studies regarding the production of this genetic group, and so further research in this sector is necessary.

In terms of productive system, the time of permanence on concentrate diets may influence the profitability of production, mainly due to the high costs of concentrates, requiring evaluation of body traits in vivo for better guidance concerning the time for slaughter. In this regard, ultrasound imaging stands out among the available techniques: according to Peres et al. (2010), it improves the prediction of the body composition, especially in the measurement of the loin-eye area and degree of fat thickness, which are widely used in cattle and sheep (NUBIATO et al., 2013). According to Osório et al. (2012), the ideal time for slaughter should be determined based on the proportion of fat suitable to the consumer preference.

Meat is the most important source of animal protein in the human diet, and its quality is defined by two aspects: the physicochemical analyses, which have an objective definition, measurable scientifically to determine the actual product quality; and the criteria referring to the consumers' concept and their search for healthier foods (MUCHENJE et al., 2009).

Thus, the physicochemical traits of the meat are important in that influence the consumers' acceptability. Among these traits, the most outstanding are the $\mathrm{pH}$ measurements performed at slaughter and after $24 \mathrm{~h} 00$ of chilling, cooking loss, shear force, and sarcomere length (MARTÍNEZCEREZO et al., 2005; ZEOLA et al., 2011).

The objective of this study was to evaluate the physicochemical composition of feedlot-finished lambs of the pantaneiro genetic group slaughtered with subcutaneous fat thicknesses of 2.0,3.0, and $4.0 \mathrm{~mm}$, evaluated by ultrasound. 


\section{Materials and Methods}

The experiment was conducted on the Experimental Farm of Iguatemi, at Universidade Estadual de Maringá (UEM), Maringá-PR, Brazil, from October 2012 to January 2013.

Twenty-four lambs of the pantaneiro genetic group at approximately 100 days of age, with an initial average weight of $16.24 \pm 1.78 \mathrm{~kg}$, acquired from extensive-rearing properties in the southwest region of Mato Grosso State were utilized in this experiment.

The animals were distributed at random into individual covered stalls with slatted suspended floor, and the treatments were defined as the subcutaneous fat thicknesses (SFT) of 2.0, 3.0, and $4.0 \mathrm{~mm}$ in the loin, between the $12^{\text {th }}$ and $13^{\text {th }}$ ribs, evaluated by ultrasound. Animals received water ad libitum throughout the experimental period, and were fed a mixed, pelleted ration formulated to provide a daily weight gain of $0.300 \mathrm{~kg}$ animal ${ }^{-1}$ (NRC, 2007). The experimental diet was supplied once daily in the morning, ad libitum, in an amount calculated to allow for leftovers of approximately $10 \%$ of the total supplied.

The chemical composition of the diet (Table 1) was determined in the Laboratory of Animal Nutrition and Feeding, at the Department of Animal Science of UEM, according to AOAC (2000) methodologies.

Table 1. Composition, in $\mathrm{g} \mathrm{kg}^{-1}$ fresh matter, of the ingredients that composed the experimental diet, and chemical composition of the experimental diet.

\begin{tabular}{lc}
\hline Ingredient & Composition $\left(\mathrm{g} \mathrm{kg}^{-1}\right)$ \\
\hline Centesimal composition of the experimental diet & \\
Oat hay & 100.0 \\
Ground corn grain & 448.0 \\
Soybean meal & 150.0 \\
Rice hulls & 150.0 \\
Rice bran & 100.0 \\
Molasses powder & 20.0 \\
Ammonium chloride & 20.0 \\
Mineral mix ${ }^{1}$ & 10.0 \\
Bacitracin zinc & 02.0 \\
Total & 1000.0 \\
\hline Diet's chemical composition variables & \\
Dry matter & 912.8 \\
Crude protein & 162.4 \\
Ether extract & 42.1 \\
Neutral detergent fiber & 275.4 \\
Acid detergent fiber & 138.6 \\
Ash & 45.9 \\
Calcium & 02.8 \\
Phosphorus & 04.0 \\
In vitro dry matter digestibility & 782.5 \\
Total digestible nutrients & 766.8 \\
\hline
\end{tabular}

${ }^{1}$ Guaranteed levels of the mineral mix per kg: calcium - $220 \mathrm{~g}$; phosphorus - $130 \mathrm{~g}$; magnesium - $25.5 \mathrm{~g}$; sulfur - $24 \mathrm{~g}$; iron - 3,000 mg; manganese - 1,500 mg; zinc - 4,000 mg; copper - 1,200 mg; cobalt - $280 \mathrm{mg}$; iodine - $260 \mathrm{mg}$; selenium - $30 \mathrm{mg}$; fluoride - $300 \mathrm{mg}$. 
The ultrasound and weighting evaluations were performed every 15 days. To obtain the subcutaneous fat thickness, an ultrasound (Honda ${ }^{\circledR}$, model HS-1500 VET) device with a 50-mm width multifrequency linear transducer was used at a frequency of $7.5 \mathrm{MHz}$. To take the measurements, the lambs were immobilized manually, and, using a comb, their fleece was separated at the measurement areas and mucilage was applied for better sliding of the transducer on the skin.

The pressure at the transducer head was kept minimal to prevent compression of the fat, and all measurements were taken by the same technician, on the left side, between the $12^{\text {th }}$ and $13^{\text {th }}$ ribs, at $4 \mathrm{~cm}$ from the spine midline. After the image was captured, the subcutaneous fat thickness was measured by using the electronic cursor of the ultrasound device.

As the lambs reached the predetermined subcutaneous thicknesses of 2.0, 3.0, and $4.0 \mathrm{~mm}$ in the fortnightly evaluation by ultrasound, they were slaughtered the day after the measurements, regardless of their weight.

After a feed-deprivation period of $18 \mathrm{~h} 00$ the animals were stunned by electronarcosis through an electric discharge of 220 Volts for 8 seconds. After bleeding, skinning, and evisceration, the carcasses were weighed and subsequently stored in a cold room at $4{ }^{\circ} \mathrm{C}$ for $24 \mathrm{~h} 00$. The $\mathrm{pH}$ was measured in the animals' loin using a pH meter (Hanna HI 996163) with a penetrating electrode. The $\mathrm{pH}$ at $0 \mathrm{~h} 00$ was computed after slaughter, and the $\mathrm{pH}$ at $24 \mathrm{~h} 00$ after chilling was measured after the carcasses spent one day in a cold room.

After chilling, the carcasses were weighed and sawn lengthwise. The longissimus dorsi muscle was taken from each left half-carcass and separated into thoracic and lumber regions, labeled, vacuumpacked, and frozen at $-18^{\circ} \mathrm{C}$.

Between the $6^{\text {th }}$ and $10^{\text {th }}$ thoracic vertebrae, samples were collected for chemical analyses, in which the moisture, mineral matter, and crude protein were determined according to AOAC
(2000) methodologies. For total lipids, extraction was performed using the technique described by Folch et al. (1957), with a chloroform-methanol ${ }^{-1}$ $\left(2: 1 \mathrm{v} \mathrm{v}^{-1}\right)$ solution.

Cooking loss (CL) and shear force were analyzed between the $11^{\text {th }}$ and $13^{\text {th }}$ thoracic vertebrae. To determine the $\mathrm{CL}$, the samples were previously defrosted for $24 \mathrm{~h} 00$ under refrigeration $\left(4{ }^{\circ} \mathrm{C}\right)$ and cut into $2.5-\mathrm{cm}$-thick stakes and weighed. Next, they were wrapped in aluminum foil, and baked on a grill at $170{ }^{\circ} \mathrm{C}$ until their geometric center reached $70{ }^{\circ} \mathrm{C}$, which was monitored through a thermometer coupled to a digital reader. Upon reaching 70 ${ }^{\circ} \mathrm{C}$ samples were taken off the grill, dried with absorbent paper, and weighed. The cooking loss was calculated as the difference in weight of the samples before and after cooking, expressed as percentage.

Shear force was determined according to the Warner-Bratzler Shear Force - WBSF (WHEELER, 2007) analysis protocol. The cooked stakes, used previously to determine the cooking loss, were left to sit at room temperature for 30 minutes. Brickshaped cuts measuring $1.0 \times 1.0 \times 3.0 \mathrm{~cm}$ were made later according to the fiber orientation. The strength necessary to cut each sample transversally was measured in a texturometer (TAXT2; Stable Micro System, Surrey, England) equipped with a Warner-Bratzler attachment, operating at a speed of $20 \mathrm{~cm} \mathrm{~s}^{-1}$. The average of eight cuts from each sample of shear force represented the toughness value of each stake, expressed in kgf.

To measure the sarcomere length, chilled samples of the longissimus dorsi were collected and fixed in $10 \%$ buffered formalin for $24 \mathrm{~h} 00$. Subsequently the samples were processed for paraffin embedding.

Semi-serial $6-\mu \mathrm{m}$-thick longitudinal histological sections were obtained with a microtome. The cuts were distended in histological water bath at $45{ }^{\circ} \mathrm{C}$ and transferred to labeled slides. The slides were placed on a wood support and incubated at $60{ }^{\circ} \mathrm{C}$ for $24 \mathrm{~h} 00$ to provide greater adherence between the paraffin and the slide. 
After deparaffinization in an oven at $60{ }^{\circ} \mathrm{C}$, samples were washed in running water for 2 minutes and treated with an aqueous solution of $0.25 \%$ potassium permanganate for 10 minutes, and then washed in running water for another 3 minutes. Next, they were immersed in oxalic acid for 5 minutes, removed, and washed in running water again for another 3 minutes and stained with 10\% Mallory phosphotungstic acid-haematoxylin, $0.5 \mathrm{~g}$ hematoxylin, and $1 \mathrm{~mL}$ hydrogen peroxide in a total volume of $500 \mathrm{~mL}$ for $24 \mathrm{~h} 00$. This stain was conditioned in an amber vial and stabilized two to three days before use.

The sections were analyzed in an optical microscope and photographed with an attached capture camera with 100 times objective and 10 times eyepiece oil-immersion lenses (Figure 1). The formatting of images, scales and measures were performed using the Motic Images Plus 2.0 software. Five animals were assessed per treatment, and the average sarcomere length $(\mu \mathrm{m})$, obtained by determining the length $(\mu \mathrm{m})$ of 10 sarcomeres from 20 distinct fibers chosen at random, was calculated in each treatment, generating a total of 200 observations per animal.

Figure 1. Photomicrography of muscle fibers of the longissimus dorsi muscle displaying the A (dark) and I (light) bands. Staining: Mallory phosphotungstic acid hematoxylin. 1000 times magnification.

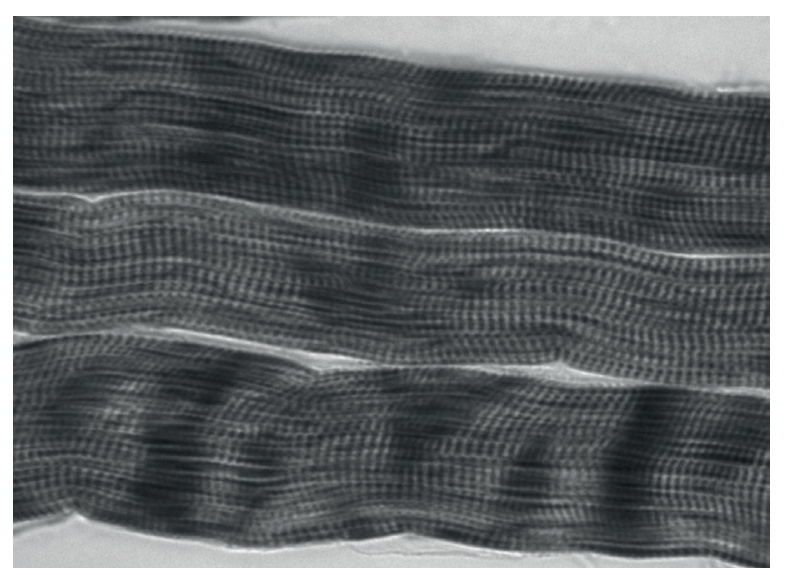

The color was evaluated in 5.0-cm-thick stakes between the $1^{\text {st }}$ and $6^{\text {th }}$ lumbar vertebrae. Measurements were taken using a colorimeter (KONICA MINOLTA CR-410) operating in the CIE $\left(L^{*}, a^{*}, b^{*}\right)$ system, in which $L^{*}$ stands for lightness, $a^{*}$ represents the intensity of red color, and $b^{*}$ is the intensity of the yellow color. The measures were taken in three different points of the stakes, and the average $L^{*}, a^{*}$ and $b^{*}$ values recorded.

Statistical analysis was performed using the Statistical Analysis System - SAS (2001) software. The experimental design was completely randomized, with three treatments and eight replicates, considering the different subcutaneous fat thicknesses at slaughter (2.0, 3.0, and $4.0 \mathrm{~mm})$. Means were compared by Tukey's test at 5\% significance.

\section{Results and Discussion}

The $\mathrm{pH}$ values obtained for $0 \mathrm{~h} 00$ and $24 \mathrm{~h} 00$ (Table 2) did not differ ( $\mathrm{P}>0.05)$ among the different SFT treatments, averaging 6.58 and 5.50 , respectively. These values are considered to be within the standard range for meats deemed normal (ZEOLA et al., 2007; SIQUEIRA et al., 2001). Muchenje et al. (2009) associated low pH values, 5.5 to 5.6, with favorable animal welfare conditions pre-slaughter, because for this to take place, glycogen is utilized in the postmortem transformation for anaerobic production of ATP, generating the lactic acid, which causes a decline in the meat $\mathrm{pH}$. If the pre-slaughter glycogen reserves are smaller, less lactic acid is formed, and thus the final meat $\mathrm{pH}$ will be higher, causing the meat to become darker. 
Table 2. Means and standard deviations for the $\mathrm{pH}$ and color values of the longissimus dorsi muscle from pantaneiro lambs slaughtered with different subcutaneous fat thicknesses (mm).

\begin{tabular}{lcccc}
\hline \multirow{2}{*}{ Variable } & \multicolumn{3}{c}{ Subcutaneous fat thickness } & \multirow{2}{*}{ CV (\%) } \\
\cline { 2 - 4 } pH 0h00 & $2.0 \mathrm{~mm}$ & $3.0 \mathrm{~mm}$ & $4.0 \mathrm{~mm}$ & 3.43 \\
$\mathrm{pH} \mathrm{24h00}$ & $6.61 \pm 0.08 \mathrm{a}$ & $6.60 \pm 0.08 \mathrm{a}$ & $6.50 \pm 0.09 \mathrm{a}$ & 2.39 \\
$\mathrm{~L}^{*}$ & $5.42 \pm 0.04 \mathrm{a}$ & $5.45 \pm 0.04 \mathrm{a}$ & $5.50 \pm 0.05 \mathrm{a}$ & 5.31 \\
$\mathrm{a}^{*}$ & $40.70 \pm 0.79 \mathrm{a}$ & $40.34 \pm 0.70 \mathrm{a}$ & $37.12 \pm 0.74 \mathrm{~b}$ & 7.13 \\
$\mathrm{~b}^{*}$ & $14.63 \pm 0.42 \mathrm{~b}$ & $17.59 \pm 0.40 \mathrm{a}$ & $18.20 \pm 0.45 \mathrm{a}$ & 9.64 \\
\hline
\end{tabular}

Means followed by the same letters in the rows indicate that there were no differences by Tukey's test $(\mathrm{P}>0.05)$.

The meat color values of the antaneiro lambs slaughtered with different SFT are shown in Table 2. The meat from the sheep slaughtered with 2.0 and $3.0 \mathrm{~mm}$ SFT had greater intensity of brightness $\left(\mathrm{L}^{*} ; \mathrm{P}<0.05\right)$ than those slaughtered with 4.0 $\mathrm{mm}$ SFT. For the $\mathrm{L}^{*}$ index, the meat from lambs slaughtered with 2.0 and $3.0 \mathrm{~mm}$ SFT displayed greater lightness, possibly due to the greater difference in age necessary for them to reach 4.0 $\mathrm{mm}$ in thickness. In younger animals, the muscle has a smaller amount of fat and higher percentage of water, which promotes lightness to the meat (SILVA SOBRINHO et al., 2005; MOLONEY et al., 2012).

The red $\left(a^{*}\right)$ and yellow $\left(b^{*}\right)$ intensity values, however, were highest in the lambs slaughtered with the largest SFT $(\mathrm{P}<0.05)$. The values displayed for the $\mathrm{a}^{*}$ and $\mathrm{b}^{*}$ intensities in meat indicated $\mathrm{a}$ significant increase between the SFT of 2.0 and 3.0 $\mathrm{mm}$. An increase in pantaneiro lambs' slaughter age usually originates meat with a darker red tone, yet within a normal range for sheep (PINHEIRO et al., 2009).

The treatments were similar $(\mathrm{P}>0.05)$ for $\mathrm{CL}$ (Table 3), which averaged $23.99 \%$, which is below the values obtained by Costa et al. (2011b), who evaluated Santa Inês (40.9\%), Dorper $\times$ Santa Inês (39.8\%), and undefined-breed (38.2\%) lambs. Similarly, working with Ile de France lambs, Zeola et al. (2011) obtained a CL value of $44.23 \%$. The results found in the present experiment suggest that the SFT interferes positively with the reduction of CL, which is directly related to the amount of water (LAWRIE, 1981) and fat (SAFFLE; BRATZLER, 1959) in the meat, which should be evaluated, since these are directly correlated with juiciness at the time of consumption.

According to Oillic et al. (2011), during cooking, the meat may lose a large amount of its mass as juice ( $90 \%$ water), which will consequently reduce, besides juiciness, the nutritional value of the product.

Table 3. Means and standard deviations for the cooking loss, shear force, and sarcomere length in meat from pantaneiro lambs slaughtered with different subcutaneous fat thicknesses ( $\mathrm{mm})$.

\begin{tabular}{lcccc}
\hline \multirow{2}{*}{ Variable } & \multicolumn{3}{c}{ Subcutaneous fat thickness } & \multirow{2}{*}{ CV (\%) } \\
\cline { 2 - 4 } & $2.0 \mathrm{~mm}$ & $3.0 \mathrm{~mm}$ & $4.0 \mathrm{~mm}$ & 23.79 \\
Cooking loss $(\%)$ & $22.47 \pm 2.02 \mathrm{a}$ & $24.57 \pm 22.02 \mathrm{a}$ & $24.93 \pm 2.02 \mathrm{a}$ & 26.83 \\
Shear force $(\mathrm{kgf})$ & $2.52 \pm 0.18 \mathrm{a}$ & $1.87 \pm 0.18 \mathrm{ab}$ & $1.43 \pm 0.18 \mathrm{~b}$ & 2.16 \\
Sarcomere length $(\mu \mathrm{m})$ & $1.37 \mathrm{~b}$ & $1.40 \mathrm{~b}$ & $1.47 \mathrm{a}$ & \\
\hline
\end{tabular}

Means followed by the same letters in the rows indicate that there were no differences by Tukey's test $(\mathrm{P}>0.05)$. 
The observed values for shear force indicate that the meat from lambs slaughtered with $4.0 \mathrm{~mm}$ SFT was more tender $(\mathrm{P}<0.05)$ than the samples originating from those slaughtered with $2.0 \mathrm{~mm}$ SFT. However, the treatment with $3.0 \mathrm{~mm}$ fat did not differ from the others. Tatum et al. (1999) classified the sheep meat as tender when its shear force was below $5 \mathrm{kgf} \mathrm{cm}^{2-1}$. In this context, regardless of the treatment, the values obtained in this study characterize the meat samples as extremely tender.

The superior amount of adipose tissue had a greater influence on the meat tenderness. An increased amount of fat in the meat provides a sensation of juiciness and stimulates salivary flow during chewing (SILVA SOBRINHO et al., 2005), which helps to improve the expression of the organoleptic senses and the consumer's acceptance at the moment of purchase.

According to Andrade et al. (2010), the shear force can be used to evaluate the meat tenderness, wherein the highest value obtained in the texturometer corresponds to the greatest strength necessary to disrupt the sample, and thence tougher meats. Higher or lower values for shear force, according to Sañudo et al. (1997), can be found in younger animals according to the slaughter age, and perhaps, according to interactions among different rates of deposition of collagen and fat in the animal. This variation in results has been reported in the literature both for values similar to those found in the current study (LEÃO et al., 2012) and higher values (COSTA et al., 2011a; VIEIRA; FERNÁNDEZ, 2014).

Regarding the length of the sarcomeres, the animals slaughtered with $4.0 \mathrm{~mm}$ SFT showed the highest values $(\mathrm{P}<0.05)$. The greater degree of fat cover probably provided a slower chilling of the carcass in the cold chamber, contributing to minimizing the harmful effects of cold on the meat tenderness (PRADO; FELÍCIO, 2010). In this regard, Vieira and Fernández (2014) reported the influence of refrigeration for $24 \mathrm{~h} 00$ on the sarcomere length, which may be reduced by 20 to $25 \%$, and thus cause muscle hardening. These authors observed similar values to those of this study, evaluating different forms of chilling both aged and non-aged lamb carcasses (conventional, between 1.5 and $1.6 \mu \mathrm{m}$; ultra fast, from 1.2 to 1.4 $\mu \mathrm{m}$; and slow, at $1.7 \mu \mathrm{m})$.

In a pioneering study, Penny and Dransfield (1979) reported that muscles with shorter sarcomere result in tougher meat, which is influenced by the location of the muscle, carcass chilling speed (VIEIRA; FERNÁNDEZ, 2014), speed of proteolysis (HWANG et al., 2004), rigor mortis stage (COSTA et al., 2011a), and body weight at slaughter (MARTÍNEZ-CEREZO et al., 2005).

The mean values for moisture, crude protein, total lipids, and mineral matter in the meat from the lambs slaughtered with different SFT (mm) can be viewed in Table 4.

Table 4. Means and standard deviations for the chemical composition of meat from pantaneiro lambs slaughtered with different subcutaneous fat thicknesses (mm).

\begin{tabular}{lcccc}
\hline \multirow{2}{*}{ Item (\%) } & \multicolumn{3}{c}{ Subcutaneous fat thickness } & \multirow{2}{*}{ CV $(\%)$} \\
\cline { 2 - 4 } & $2.0 \mathrm{~mm}$ & $3.0 \mathrm{~mm}$ & $4.0 \mathrm{~mm}$ & \\
\hline Moisture & $72.38 \pm 053 \mathrm{a}$ & $71.19 \pm 0.53 \mathrm{ab}$ & $70.39 \pm 0.53 \mathrm{~b}$ & 2.10 \\
Crude protein & $21.15 \pm 0.34 \mathrm{a}$ & $20.32 \pm 0.34 \mathrm{ab}$ & $19.75 \pm 0.34 \mathrm{~b}$ & 4.652 \\
Total lipids & $2.79 \pm 0.31 \mathrm{~b}$ & $3.76 \pm 0.31 \mathrm{ab}$ & $4.84 \pm 0.31 \mathrm{a}$ & 23.19 \\
Mineral matter & $1.87 \pm 013 \mathrm{a}$ & $1.88 \pm 0.13 \mathrm{a}$ & $1.87 \pm 0.13 \mathrm{a}$ & 19.58 \\
\hline
\end{tabular}

Means followed by the same letters in the rows indicate that there were no differences by Tukey's test $(\mathrm{P}>0.05)$. 
As regards the chemical composition of sheep meat, it is known that it has mean values of $75 \%$ moisture, $19 \%$ protein, $4 \%$ fat, and 1\% mineral matter, with possible variations (PRATA, 1999). The percentage of mineral matter was similar $(\mathrm{P}>0.05)$ among the treatments, averaging $1.87 \%$, which explains that in the mineralized animal, alterations in this component do not occur significantly due to the low percentage of this component in its constitution.

For crude protein and moisture, the results from the treatment with $2.0 \mathrm{~mm}$ SFT were higher $(\mathrm{P}<0.05)$ than those from the lambs slaughtered with $4.0 \mathrm{~mm}$ SFT. The animals slaughtered with $3.0 \mathrm{~mm}$ SFT were not different from the others. The lipid content in the meat from the lambs slaughtered with $4.0 \mathrm{~mm}$ SFT was higher $(\mathrm{P}<0.05)$ than that in the meat from the $2.0 \mathrm{~mm}$ SFT treatment.

These results are thus consistent as they reassert that the chemical composition of the meat varies according to the animal growth and is influenced by age and nutrition. According to Ferreira et al. (1998), young animals have a greater proportion of water and protein in the body, which decrease with ageing and weight gain. Lambs slaughtered with $4.0 \mathrm{~mm}$ SFT remained confined longer, because they required a greater supply of nutrients to reach the predetermined SFT, which explains the proportional inversion of the moisture, protein, and fat values reported in this study.

The percentages of lipids in the meat of pantaneiro lambs slaughtered with $4.0 \mathrm{~mm}$ SFT were greater than those found in the literature (BONACINA et al., 2011; LOPES et al., 2012). In this regard, Pethick et al. (2004) reported that deposition of body fat follows some priority order, wherein the first one is perirenal fat, followed by the fat between the muscle groups, then the subcutaneous fat, and lastly the marbling fat. This explains the increased intramuscular fat in the lambs slaughtered with $4.0 \mathrm{~mm}$ SFT.

It is recommended to slaughter pantaneiro lambs with a subcutaneous fat thickness of $3.0 \mathrm{~mm}$ in the loin, because they comprise a larger number of favorable traits regarding the meat chemical composition, tenderness, and color.

\section{References}

ANDRADE, P. L.; BRESSAN, M. C.; GAMA, L. T.; GONÇALVES, T. M.; LADEIRA, M. M.; RAMOS, E. E. Qualidade da carne maturada de bovinos Red Norte e Nelore. Revista Brasileira de Zootecnia, Viçosa, MG, v. 39, n. 8, p. 1791-1800, 2010.

ASSOCIATION OF OFFICIAL ANALYTICAL CHEMISTIS - AOAC. Official methods of analysis. 13. ed. Arlington: AOAC International, 2000. 989 p.

BONACINA, M. S.; OSÓRIO, M. T. M.; OSÓRIO, J. C. S.; CORRÊA, G. F.; HASHIMOTO, J. H. Influência do sexo e do sistema de terminação de cordeiros Texel $\times$ Corriedale na qualidade da carcaça e da carne. Revista Brasileira Zootecnia, Viçosa, MG, v. 40, n. 6, p. 1242-1249, 2011.

COSTA, R. G.; SANTOS, N. M.; SOUSA, W. H.; QUEIROGA, C. R. E.; AZEVEDO, P. S.; CARTAXO, F. Q. Qualidade física e sensorial da carne de cordeiros de três genótipos alimentados com rações formuladas com duas relações volumoso:concentrado. Revista Brasileira de Zootecnia, Viçosa, MG, v. 40, n. 8, p. 1781-1787, 2011a.

COSTA, R. S.; HENRY, F. C.; QUIRINO, C. R.; HENRIQUES, L. S. V.; CARVALHO, E. C. Q.; ALMEIDA, S. B. Caracterização do processo de rigor mortis em músculos de cordeiros da raça Santa Inês e F1 Santa Inês x Dorper. Revista de Ciências Agrárias, Recife, v. 34, n. 1, p. 143-153, 2011 b.

FERREIRA, M. A.; VALADARES FILHO, S. C.; COELHO da SILVA, J. F.; VALADARES, R. F. D.; PAULINO, M. F.; CECON, P. R. Composição corporal e exigências líquidas de proteína e energia para ganho de peso de bovinos F1 Simental X Nelore. Revista Brasileira Zootecnia, Viçosa, MG, v. 28, n. 2, p. 352-360, 1998.

FOLCH, J.; LESS, M.; SLOANE, S. G. H. A simple method for the isolation and purification of total lipids from animal tissues. The Journal of Biological 
Chemistry, Rockville, v. 226, n. 1, p. 497-509, 1957.

HWANG, I. H.; PARK, B. Y.; CHO, S. H.; LEE, J. M. Effects of muscle shortening and proteolysis on Warner-Bratzler shear force in beef longissimus and semitendinosus. Meat Science, Cowra, v. 68, n. 3, p. 497-505, 2004.

LAWRIE, R. Developments in meat science. London: Elsevier Applied Science, 1981. 342 p.

LEÃO,A.G.; SILVASOBRINHO,A. G.; MORENO, G. M. B.; SOUZA, H. B. A.; GIAMPIETRO, A.; ROSSI, R. C.; PEREZ, H. L. Características físico-químicas e sensoriais da carne de cordeiros terminados com dietas contendo cana-de-açúcar ou silagem de milho e dois níveis de concentrado. Revista Brasileira de Zootecnia, Viçosa, MG, v. 41, n. 5, p. 1253-1262, 2012.

LOPES, J. E. L.; SALES, R. O.; AZEVEDO, A. R.; OLIVEIRA, A. L. T. Composição centesimal, perfil de ácidos graxos e colesterol da carne de cordeiros submetidos aos sistemas de produção com dieta experimental e convencional. Revista Brasileira de Higiene e Sanidade Animal, Fortaleza, v. 6, n. 2, p. 31-50, 2012.

MARTÍNEZ-CEREZO, S.; SAÑUDO, C.; PANEA, B.; OLLETA, J. L. Breed, slaughter weight and ageing time effects on consumer appraisal of three muscles of lamb. Meat Science, Cowra, v. 69, n. 2, p. 795-805, 2005.

MISSIO, R. G.; BRONDANI, I. L.; ALVES FILHO, D. C.; RESTLE, J.; ARBOITTE, M. Z.; SEGABINAZZI, L. R. Características da carcaça e da carne de tourinhos terminados em confinamento, recebendo diferentes níveis de concentrado na dieta. Revista Brasileira de Zootecnia, Viçosa, MG, v. 39, n. 7, p. 1610-1617, 2010.

MOLONEY, A. P.; KENNNEDY, C.; NOCI, F.; MONAHAN, F. J.; KERRY, J. P. Lipid and colour stability of longissimus muscle from lambs fed camelina or linseed as oil or seeds. Meat Science, Cowra, v. 92, n. 1, p. 1-7, 2012.

MUCHENJE, V.; DZAMAC, B. K.; CHIMONYOA, M. P. E.; STRYDOMD, A.; HUGOE, A.; RAATS, J. G. Some biochemical aspects pertaining to beef eating quality and consumer health: a review. Food Chemistry, Reading, v. 112, n. 2, p. 279-289, 2009.
NATIONAL RESEARCH COUNCIL - NRC. Nutrient requirements of small ruminants: sheep, goats, cervids, and new world camelids. Washington, D.C.: National Academy Press, 2007. 384 p.

NUBIATO, K. E. Z.; FERNANDES, A. R. M.; ALVES, L. G. C.; OSÓRIO, J. C. S.; OSÓRIO, M. T. M.; CUNHA, C. M.; CORNÉLIO, T. C.; CATALANO NETO, A. P. A técnica do ultrassom para avaliação da carcaça em tempo real. PUBVET, Londrina, v. 7, n. 8, p. 1-10, 2013.

OILLIC, S.; LEMOINE, E.; GROS, J. B.; KONDJOYAN, A. Kinetic analysis of cooking losses from beef and other animal muscles heated in a water bath: Effect of sample dimensions and prior freezing and ageing. Meat Science, Cowra, v. 88, n. 3, p. 338-346, 2011.

OSÓRIO, J. C. S.; OSÓRIO, M. T. M.; VARGAS JUNIOR, F. M.; FERNANDES, A. R. M.; SENO, L. O.; RICARDO, H. A.; ROSSINI, F. C.; ORRICO JUNIOR, M. A. P. Critérios para abate do animal e a qualidade da carne. Revista Agrarian, Dourados, v. 5, n. 18, p. 433-443, 2012.

PENNY, I. F.; DRANSFIELD, E. Relationship between toughness and troponin $\mathrm{T}$ in conditioned beef. Meat Science, Cowra, v. 3, n. 2, p. 135-141, 1979.

PERES, A. M.; DIAS, L. G.; JOY, M.; TEIXEIRA, A. Assessment of goat carcass fat composition using ultrasound technology and multiple multivariate prediction models. Journal Animal Science, Champaign, v. 88, n. 2, p. 572-580, 2010.

PETHICK, D. W.; HARPER, G. S.; ODDY, V. H. Growth, development and nutritional manipulation of marbling in cattle: a review. Australian Journal of Experimental Agriculture, Clayton SouthMelboune, v. 44, n. 4, p. 705-715, 2004.

PINHEIRO, R. S. B.; SILVA SOBRINHO, A. G.; SOUZA, H. B. A.; YAMAMOTO, S. M. Qualidade de carnes provenientes de cortes da carcaça de cordeiros e de ovinos adultos. Revista Brasileira de Zootecnia, Viçosa, MG, v. 38, n. 9, p. 1790-1796, 2009.

PRADO, C. S.; FELÍCIO, P. E. Effects of chilling rate and spray-chilling on weight loss and tenderness in beef strip loin steaks. Meat Science, Cowra, v. 86, n. 2, p. 430-435, 2010. 
PRATA, L. F. Higiene e inspeção de carnes, pescado e derivados. Jaboticabal: FUNEP, 1999. 217 p.

SAFFLE, R. L.; BRATZLER, L. J. The effect of fatness on some processing and palatability characteristics of pork carcasses. Food technology, Chicago, v. 13, n. 1, p. 236-241, 1959.

SAÑUDO, C.; CAMPO, C. C.; SIERA, I.; MARÍA, G. A.; OlletA, J. L.; SANTOLARIA, P. Breed effect on carcass and meat quality of suckling lambs. Meat Science, Cowra, v. 46, n. 4, p. 357-365, 1997.

SILVA SOBRINHO, A. G.; PURCHAS, R. N.; KADIM, I. T. Musculosidade e composição da perna de ovinos de diferentes genótipos e idades de abate. Pesquisa Agropecuária Brasileira, Brasília, v. 40, n. 11, p. 1129-1134, 2005.

SIQUEIRA, E. R.; SIMÕES, C. D.; FERNANDES, S. Efeito do sexo e do peso ao abate sobre a produção de carne de cordeiros. I. velocidade de crescimento, caracteres quantitativos da carcaça, ph da carne e resultados econômicos. Revista Brasileira de Zootecnia, Viçosa, MG, v. 30, n. 3, p. 844-848, 2001.

STATISTICAL ANALYSIS SYSTEM - SAS. SAS user's guide: statistics. 5. ed. Cary: 2001. 956 p.

TATUM, J. D.; SMITH, G. C.; BELK, K. E. New approaches for improving tenderness, quality and connsistency of beef. In: PROCEEDINGS OF THE ANIMAL SOCIETY OF ANIMAL SCIENCE, Indianapolis, 1999, Indianapolis. Proceedings... Indianapolis: American Society of Animal Science, 1999. p. 1-10.
VARGAS JUNIOR, F. M.; MARTINS, C. F.; SOUZA, C. C.; PINTO, G. S.; PEREIRA, H. F.; CAMILO, F. R.; AZEVEDO JUNIOR, N. P. Avaliação Biométrica de Cordeiros Pantaneiros. Revista Agrarian, Dourados, v. 4, n. 11, p. 60-65, 2011.

VIEIRA, C.; FERNÁNDEZ, A. M. Effect of ageing time on suckling lamb meat quality resulting from different carcass chilling regimes. Meat Science, Cowra, v. 96, n. 2, p. 682-687, 2014.

WHEELER, T. L.; SCHACKELFORD, S. D.; KOOHMARIE, M. Beef longissimus slice shear force measurement among steak locations and institutions. Journal Animal Science, Champaign, v. 85, n. 9, p. 2283-2289, 2007.

ZEOLA, N. M. B. L.; SILVA SOBRINHO, A. G.; MANZI, G. M. Parâmetros qualitativos da carne de cordeiros submetidos aos modelos de produção orgânico e convencional. Brazilian Journal of Veterinary Research and Animal Science, São Paulo, v. 48, n. 2, p. 107-115, 2011.

ZEOLA, N. M. B. L.; SOUZA, P. A.; SOUZA, H. B. A.; SILVA SOBRINHO, A. G. Parâmetros qualitativos da carne ovina: um enfoque à maturação e marinação. Revista Portuguesa de Ciências Veterinárias, Lisboa, v. 102, n. 2, p. 215 224, 2007. 